\begin{tabular}{|l|l|l||}
\hline \multicolumn{2}{|c|}{ PublisherInfo } \\
\hline \hline PublisherName & $:$ & BioMed Central \\
\hline \hline PublisherLocation & $:$ & London \\
\hline \hline PublisherImprintName & $:$ & BioMed Central \\
\hline \hline
\end{tabular}

\title{
Eukaryotic origins
}

\begin{tabular}{|l|l|l||}
\hline \multicolumn{2}{|c|}{ ArticleInfo } \\
\hline \hline ArticleID & $:$ & 4395 \\
\hline \hline ArticleDOI & $:$ & $10.1186 /$ gb-spotlight-20020207-02 \\
\hline \hline ArticleCitationID & $:$ & spotlight-20020207-02 \\
\hline \hline ArticleSequenceNumber & $:$ & 61 \\
\hline \hline ArticleCategory & $:$ & Research news \\
\hline ArticleFirstPage & $:$ & 1 \\
\hline \hline ArticleLastPage & $:$ & 2 \\
\hline \hline & & RegistrationDate : 2002-2-7 \\
\hline ArticleHistory & $:$ & OnlineDate \\
\hline \hline ArticleCopyright & $:$ & BioMed Central Ltd2002-7 \\
\hline \hline ArticleGrants & $:$ & \\
\hline \hline ArticleContext & $:$ & 130593311 \\
\hline \hline
\end{tabular}




\section{Jonathan B Weitzman}

Email: jonathanweitzman@hotmail.com

In the February 5 Proceedings of the National Academy of Sciences, Hartman and Fedorov describe the use of a genomic approach to investigate the relationship between Eukarya, Archaea and Bacteria (Proc Natl Acad Sci USA 2002, 99:1429-1425). They defined a set of several hundred 'eukaryotic signature proteins' (ESPs), that have no homologs in Archaea or Bacteria. The 347 ESPs include cytoplasmic proteins, internal signalling proteins and nuclear proteins. Hartman and Fedorov used their results to test the hypothesis that the nucleus was formed from the endosymbiosis of an archeon and a bacterium inside a third cell called a 'chronocyte'. Their analysis predicts that the chronocyte was an RNA-based cell that engulfed prokaryotic cells. This hypothesis is supported by the nature of the ESP collection. The cytoplasmic ESPs include proteins involved in the cytoskeleton and phagocytosis. Internal ESPs regulate signalling through calcium ions, calmodulin, ubiquitin, GTP-binding proteins, and so forth. The nuclear ESP set is dominated by proteins important for processing and transport of nuclear RNAs into the cytoplasm. Hartman and Fedorov state that a full reconstruction of the chronocyte will require additional well-annotated eukaryotic sequenced genomes.

\section{References}

\section{Proceedings of the National Academy of Sciences, [http://www.pnas.org]}

2. An archaeal genomic signature.

3. The origin of the eukaryotic cell: A genomic investigation, [http://www.mcb.harvard.edu/gilbert/ $\mathrm{ESP} /]$ 